\title{
Management of loyalty in developing a company's brand on the Russian oil and gas B2B market
}

\author{
$N V$ Puzina*, $A A$ Vereteno, $E A$ Luneva and $N V$ Katunina \\ Omsk State University, 644077, 11 Neftezavodskaya Str., Omsk, Russia
}

\begin{abstract}
In this article, we consider the importance of lifestyle and preferences of the decision-makers as parts of management of loyalty in developing a company's brand on the Russian oil and gas B2B market. We provide the definitions of the concepts of "brand" and "loyalty", types of loyalty and development stages of a loyalty program. Additionally, we report the results of a marketing research for development of the loyalty program of the oil trading company (characteristics, opinions and preferences of the decisionmakers on the Russian market of light oil and liquefied hydrocarbon gas products).
\end{abstract}

\section{Introduction}

Current realities of market economy have reoriented businesses on the competition of brands, strengthening of which provides major advantages to the organization. The new technological revolution considerably changes shape and conditions of development of world power industry [1], including the oil and gas market. Main question for most of the organizations, especially on the B2B market, is maintaining efficiency of activity of the company and retention of a brand's position. It should be noted that there are differences between brand creation on a $\mathrm{B} 2 \mathrm{C}$ market and on a B2B market [2]; however, preservation of the current clients of the organization and ensuring their loyalty is a crucial component of any company's success [3].

The management of loyalty into shaping a brand allows to solve this problem. Brands represent important organization activity, reflecting consumer confidence and stability of business development. Moreover, the development of successful brands promotes increase in profitability of business, growth of product or service quality, image of the company, strengthening of reputation and economic security. It is possible to give as an example the Samsung Company, which actively applies policy of maintaining clients' loyalty [4].

Meanwhile it should be noted that questions of loyalty management in creating a brand in the B2B market have been researched insufficiently. The loyalty program can be considered as an element of strategy of "holding in" the client. It is especially important to develop the loyalty program if all clients are individualized [5]. Only the client-focused marketing, the main objective if which is the analysis of loyalty of clients, is among what effectively works at some Russian markets today. It is possible to include the market of oil products under study in the list of such markets (the vertically integrated companies like GazpromNeft are not considered). According to St. Petersburg International Commodity Exchange (http://spimex.com), for the period from January to June of 2019 the rating of independent brokers of the section "Oil products" shows that top ten constantly compete among themselves aspiring to beat rivals in volume of the transactions made at the exchange [6]. At the same time, each company already competes at the level of brands. Therefore, company "Solid-tovarnye rynki» on the website positions itself as a "broker No. 1" (https://www.solidtr.ru) [7]. More competitive leader of the market in June 2019, "Petroleum Trading", also declares himself as an "oil trader No. 1" (https://ptomsk.ru) [8]. Such competition at the level of brands is possible if the clients' loyalty program is developed and actualized.

Trade at the exchange for the account and for the benefit of the client is always present at the B2B market. From a position of marketing, the buyer of oil products who signs the contract with the broker is the head of the organization or the person responsible for signing of the contract on fuel purchase or change of the supplier of fuel. In management, this person is called the person making the decision. In this regard, a main objective of this work is the analysis of lifestyle and habits of the persons making decisions in the organizations clients of petrol-traders (decision-makers).

Before considering management of loyalty in the $\mathrm{B} 2 \mathrm{~B}$ market, it is necessary to consider definitions of the concepts of "brand" and "loyalty". It is necessary to understand that a brand is not only the identifier of the organization, but also (which is especially important for representation of the additional value of the organization) a certain mental model that gives an overall picture of how to react, what people think of the goods or services or the company, and what value (for buyers) is established through their constant positive experience of interaction with the company eventually [9].

* Corresponding author: puzinanv@omsu.ru 
Brand is a multidimensional coded signal [10] (economic, functional, emotional, cultural), carrying message (promise) intended to identify goods under this brand and/or the owner/user of this brand. Its task is to assign to the owner some properties on this brand and to cause the cognitive resonance in the target market connected with generation of the positive associations generated by the previous experience of consumption and/or expectations of the real and virtual community forming in the specified market. One of the results of a brand creation is readiness of the target market to pay for this brand (branded goods) more, than for analogous goods of competitors or former version of goods. Other consequences can be preservation/expansion of the target market within the life cycle of this brand (to a recession phase) and formation of the brand in question as brand capital and, respectively, transformation of a brand into subject to purchase and sale or rent [11].

The buyer's influence on the brand value (statistically subjective indicator) significantly and quickly increases in process of development of digital economy [12]. For the last 40 years, there have been drastic changes in business. It has transitioned from traditional business to electronic business where transactions are made by either e-mail or using information systems over the Internet [13]. Due to the changes, increasing level of clients' loyalty is one of instruments of impact on growth of sales [14].

Let us consider the concept of "loyalty". For many companies the loyalty is considered as an important source of competitive advantages [15]. The concept of "loyalty" is a difficult phenomenon subject to influence of a number of factors, both from the market environment, and the factors connected with behavior and the relation of consumers. In theory and in practice there is no universal, uniform definition of loyalty [16]. The concept of relationship marketing of the relations is a necessary condition of emergence of loyalty, as, on the one hand, it forms the favorable market environment, and on the other, changes management of the organization, creating necessary instruments of more effective interaction. We will understand the complex phenomenon arising as loyalty when consumers are positive to company's activity, the products and services, its personnel and everything else offered by it, and this relation, which is expressed by preference given to products of this company in comparison with competitors, is steady in time and is characterized by commission of repeated purchases.

The loyalty of buyers can be divided into loyalty to the enterprise or its location; loyalty to the brand, service, sales propositions; loyalty to the staff of the organization [17].

It is possible to carry the following to the most widespread programs of loyalty: bonuses for each purchase; program of discount cards for each client; an event with free goods; the multilevel bonus program (such program as used by oil traders).

When developing the loyalty program in the B2B market it is necessary to understand that the loyalty program increases the functional value of a brand [18]. In the environment of $\mathrm{B} 2 \mathrm{~B}$, sellers have to understand the nature and circumstances of the clients because of their unique characteristics [19]. The loyalty program is not only the instrument of stimulation clients to make purchases, but also the channel for regular interaction with clients and emotional involvement of the decisionmakers.

In the theory and in practice we can distinguish the following main development stages of loyalty programs: definition of the purpose and tasks, development of possible options for actions for increase in loyalty of the decision-makers, development of the questionnaire for detection of needs of the decision-makers and lifestyle, polling, processing of the received results, calculation of efficiency of the program and its realization.

For effective management of loyalty of partners in the B2B market it is necessary to consider communicative skills of sales managers, structure and features of functioning of the purchasing center, special offers or special benefits, which the company is ready to provide, business process automation, which strongly affects the business in general. Confidentiality of information and mutually beneficial cooperation in total with studying the behavioral and psychographic characteristics of decision-makers, and influencing the choice of the business partner in the best way allows to increase effective management of loyalty.

Decision-makers during a purchase may be looking not only for the solution to problems of the company, but also for a way to satisfy their personal needs, being guided at the same time by own valuable motives. As a result, marketing the needs of the business partner (company) consists of marketing for the employee who has his own desires and marketing for the requirements of the organization. In this regard, there is a need of studying the requirements, needs and motivations of participants of the center of decision-making. The most important direction of marketing activity of the companies engaged in marketing in the oil and gas industry is recognition and satisfaction of requirements and desires of clients [20]. It should be noted that the majority of the existing researches on management of loyalty and qualities of the relations are quantitative [21]; therefore, receiving more detailed understanding of loyalty of clients requires use of qualitative parameters of a research of the particular market.

\section{Methods}

Within the current research, the market under study is narrowed down: we have selected the market of light oil products and the liquefied hydrocarbon gas. A form of a market research - a deep telephone interview that was carried out by means of the Mangotalker program. The persons authorized to make a decision on change of the supplier participated in an interview, respondents from different regions of Russia participated; the total quantity of respondents was 100 people. The questionnaire included five parts: geographical criteria, demographic, social, psychographic and economic. The part of psychographic criteria was divided into subparts, namely: "social activity", "interests" and "opinions", in 
which preferences of respondents were studied in detail. A research objective was to make a portrait of the decision-maker and to reveal their interests and preferences for development of the loyalty program of the oil trading company. Within the research it was necessary to reveal the following: political and social activity of respondents (priority to work or family, career or income, material or moral incentive of work, hobby, vacation preferences, participation in social life of the company, the city or country, and also playing sports and what actions are attended); the interests of the decisionmakers concerning fashion, trademarks, food, media, social networks; and also opinion of respondents concerning an economic situation in the country and future development of their company. Within the economic part of the research volumes of expenses of the company on fuel, seasonality of goods, the requirement to the supplier of fuel, factors of influence on the choice of the supplier, the communication medium, elasticity of demand, a working condition and level of personal income of the decision-makers were estimated.

Distribution on the federal districts of Russia turned out rather uniform: $22 \%$ are from Siberian Federal District, $19 \%$ - Northwestern, 11\% - the North Caucasian, $10 \%$ - Ural, etc. Least of all the volume of sampling consisted of the Far Eastern Federal District residents $(2 \%)$. In total, respondents from 42 territorial subjects of the Russian Federation were interviewed.

Gender structure of respondents: $80 \%$ of respondents were men, $20 \%$ were women. The received demographic distribution does not distort results of a research as similar gender division on senior positions is characteristic of this industry.

Characteristics of the decision-makers: the dominating age groups $-35-40$ years and $41-45$ years; average family composition - three persons; nationality - the Russians (the dropping-out answers - the Tatar, the Jew), on religious preferences there was no deviations from the general trend; the vast majority have the higher education; average experience in the industry - 15.5 years; the average salary - starting at 60 thousand rubles a month.

\section{The results of the research}

The research of psychographic characteristics of respondents allowed drawing the following conclusions. Respondents do not do the unambiguous choice between work and family. In the choice between career and the income, decision-makers prefer only income. Material and moral incentive of work they put on the same level. On a question of a hobby a considerable part of respondents indicated sports, to be engaged in a country house, tourism and fishing. A research of social activity showed that the most part of respondents is not inclined to participate in any actions of social character; however, it can be explained with a lack of time and high load of the decision-makers. At the same time, many respondents do charity work. Preferences at the choice of the vacation spot incline towards vacations abroad as opposed to within the country, at the same time the vacation has to be active. However, costs of vacation should not be too high.

In their free time, decision-makers prefer to spend time with family. This conclusion correlates in the main characteristics of the decision-makers (the family man of average years). Some results of a research also showed a prevalence of interests of family of the decision-makers over personal interests.

The analysis of consumer preferences of the decision-makers revealed the preferred type of alcoholic products (wine, cognac), mineral water. While $76 \%$ of respondents do not smoke, the remained decision-makers stated preferences in tobacco products (Winston, Parliament). The brand of the producer of clothes is not important for the decision-makers. Among brands of cars, respondents have noted Toyota, Lexus, and Mercedes. In addition, preferences at the choice of banking services, brands of phone (Apple, Samsung), personal equipment (Apple, Asus) were revealed.

The part of the analysis is devoted to preferences on respondents' food. Preference is given to restaurant or cafe. At the same time, the most part of the decisionmakers prefers homemade food: generally dishes in which there is a combination of meat and vegetable products.

The analysis of media preferences of respondents showed: decision-makers watch TV regularly $(40 \%)$ or infrequently (20\%). 19\% of respondents do not watch TV at all, $13 \%$ - constantly watch TV, and $8 \%$ rather often watch TV. Preferred television channels: TNT, news channels, "Russia 1", "Pervyj kanal", NTV, "Russia-24", RBC, "Zvezda", "Informvest", sports channels, "Culture", "Domashnij", REN-TV, STS. 77\% of respondents listen to radio mainly in the car on the road ("Echo of Moscow", "Dorozhnoe radio", "Russkoe radio", "Europe plus"). Decision-makers seldom use social networks and use the news websites on the Internet.

For implementation of business communications a half of the respondent use the cell phone and e-mail as mean of communication and some use the fax, the landline phone and Skype.

According to respondents, the economic situation in the country is assessed as unstable, crisis (2017-2018).

The analysis of respondents' answers on the economic part of the questionnaire has allowed to receive the following results. The volume of the fuel company expenses is on average 20 million rubles. Generally, fuel is not considered as seasonal goods but rather constant, because fuel is necessary for business functioning and companies have oil and gas stations that need to be supplied with fuel constantly. Main types of fuel are diesel fuel and gasoline by brands 92 and 95 . Many respondents noted that not all oil plants in Russia produce the European standard types of fuel, while machines and the equipment demand high quality fuel, therefore it is necessary to check by the quality certificate whether this type of fuel is suitable for the equipment or not. The most important requirements, which are imposed by the companies to the supplier of fuel, are high quality of products $(57 \%)$, reasonable price 
$(35 \%)$, decency $(10 \%)$, reliability $(13 \%)$, delivery terms (7\%), and shipment speed (6\%). The fuel quality has to meet the requirements of the quality certificate and the state standards. Supply has to be timely and continuous, and delivery time exact. Some respondents claimed that they demand nothing, except fast shipment. The major factors influencing the choice of the supplier are the price $(35 \%)$, quality $(30 \%)$, reliability $(15 \%)$, decency $(6 \%)$, good reputation of the company $(9 \%)$, terms of delivery (5\%). Many respondents also specified that during the work with the supplier the deferred payment and also acceptable conditions of work, legal check of the company, taxation, solvency, trusting relationship is important. The analysis of price elasticity of demand showed that the most part of the interviewed respondents will not begin to change the acting supplier in case of changing in price by 50 or 100 rubles per ton. It demonstrates to low elasticity of demand at the price and importance of other factors of the choice of the partner.

The main objective of the company addressed to the supplier of fuel is receiving quality products, profit, and purchase of high quality fuel at the low price.

Results of the marketing research allow to develop actions not only for preservation of clients, but also for attraction of new ones. The innovator in this sphere can be considered "Petroleum Trading", which is on the first places in the rating of independent brokers in the Russian fuel market. The analysis of their marketing activity allows to say that this company actively manages clients' loyalty. For example, the brightest element of their loyalty program is the stock "Austrian Vacation" [22].

Thus, management of loyalty when forming a brand plays a large role for the enterprises, which work at B2B market. Studying lifestyle, behavioral characteristics and consumer preferences is necessary for development of the company's loyalty program.

\section{References}

1. S. Filippov, New Technological Revolution and Energy Requirements, Foresight and STI Governance, 12, 20-33 (2018)

2. B. Österle, M. Kuhn, J. Henseler, Brand worlds: Introducing experiential marketing to $\mathrm{B} 2 \mathrm{~B}$ branding, Industrial Marketing Management, 72, 71-98 (2018)

3. A. Haghkhah, A. Hamid, A. Ebrahimpour, P. Roghanian, H. Gheysari, Commitment and Customer Loyalty in Business-To-Business Context, European Journal of Business and Management, 5(19), 156-165 (2013)

4. M. Atashfaraz, M. Abadi, Impact Of E-Service Innovation On Brand Equality And Customer Loyality In Samsung International Corporation, Procedia Economics and Finance, 36, 327-335 (2016)

5. S. Mishra, S. Prasad, Exploring linkages between socio-demographic factors and customer loyalty in India, Management \& Marketing. Challenges for the Knowledge Society, 9(1), 13-26 (2014)
6. Sankt-Peterburgskaya Mezhdunarodnaya tovarnosyr'evaya birzha http://spimex.com/

7. Akcionernoe obshchestvo «Solid-tovarnye rynki» https://www.solid-tr.ru

8. Obshchestvo s ogranichennoj otvetstvennost'yu «Petroleum Trading» https://ptomsk.ru/

9. V. Cherenkov, A. Vereteno, Brand and branding: to the definition of the economic essence of terms, Problemy sovremennoj ekonomiki, 2 (2019)

10. V. Ginzburg, Multidimensional signals for continuous channel, Problemy peredachi informatsii, 20(1), 28-46 (1984)

11. S. Starov, V. Cherenkov, S. Kiryukov, Trademark license agreement as a branding tool, Brendmenedzhment, 1, 60-78 (2017)

12. A. Kintonova, Y. Nessipbekov, Z. Arynova, L. Kussepova, A. Karymsakova, A. Takuadina, A. Vereteno, E. Kushkov, Automation of Business Processes at the Enterprise during a Brand Formation, Journal of Interdisciplinary Research, 9 , 107-113 (2019)

13. S. Nikou, H. Selamat, R. Yusoff, M. Khiabani, Electronic Customer Relationship Management, Customer Satisfaction, and Customer Loyalty, A Comprehensive Review Study, 2, 1133-44 (2016)

14. S. Dragunov, Loyalty of clients in enterprise structures: actions for increase in loyalty and assessment of their efficiency, Izvestiya SanktPeterburgskogo gosudarstvennogo ekonomicheskogo universiteta, 3, 100-103 (2009)

15. S. Lam, V. Shankar, M. Erramilli, B. Murthy, Customer Value, Satisfaction, Loyalty, and Switching Costs: An Illustration From a Businessto-Business Service Context, Journal of the Academy of Marketing Science, 32, 293-98 (2014)

16. M.Uncle, R. Hammond, G. Dowling, Customer Loyalty and Customer Loyalty Programs, Journal of Consumer Marketing, 20(4), 294-316 (2003)

17. K. Kirillova, Loyalty of clients: a concept, possible components, ways of restoration of the lost loyalty, Ekonomika i upravlenie: analiz tendencij i perspektiv razvitiya, 3, 55-59 (2013)

18. S. Gupta, T. Gupta, G. Shainesh, Navigating from programme loyalty to company loyalty, 14th International Conference on Marketing, 28-29 (2016)

19. P. Rauyruen, K. Miller, Relationship Quality as a Predictor of B2B Customer loyalty, Journal of Business Research, 60(1), 21-31 (2007)

20. A. Alfadly, Kuwait National Petroleum Company (KNPC) Marketing Strategy in Oil Sector, International Journal of Marketing Studies, 3(1), 45-49 (2011)

21. W. Ou, C. Shih, C. Chen, K. Wang, Relationships among customer loyalty programs, service quality, relationship quality and loyalty: an empirical study, Chinese management Studies, 5(2), 194-206 (2011)

22. M. Dyachenko, Rozygrysh prizov ot kompanii «Petroleum Trejding» (2017) http://www.pressrelease.ru/branches/chemistry/7caa22a0d4573/ 